\title{
El aquí y ahora de las investigaciones (etno)musicológicas ${ }^{1}$
}

Miguel A. García

La pandemia está generando cambios a nivel global sobre el trasfondo del uso intensivo y extensivo de las tecnologías digitales. Estos cambios ocurren tanto en la organización de la vida cotidiana a través del auge del teletrabajo, el comercio electrónico, el delivery y la búsqueda de nuevas formas de comunicación y movilidad, como en las variables y condiciones de negociación que atañen a la macroeconomía y la política. La pandemia también está siendo reveladora de la magnitud de las diferencias entre ricos y pobres, de la fragilidad o inoperancia de los sistemas de salud, de la insensibilidad de varios gobiernos a la hora de sopesar las vidas de las personas y las ganancias de las empresas, del proceder puramente mercantil de los fabricantes de medicamentos, del aprovechamiento partidario del miedo y la desazón, de la existencia de un individualismo sempiterno ahora alimentado por el temor y de muchas otras mezquindades. Pero también está concibiendo la antítesis de todas esas sordideces: aquí y allá se ven florecer acciones solidarias, desinteresadas, colectivas, regidas por los principios de igualdad y justicia. En torno a este tipo de actitudes se modela a golpes de cincel una utopía que contagia tan rápido como el virus. Ella abre la posibilidad de socavar el orden pre-pandémico, de romper su perversidad con el medioambiente, de desterrar su esencia mercantil, de horadar su impronta elitista y de reorientar su pulsión acumulativa y concentradora de la riqueza. Esta utopía no es totalmente nueva, ya la conocemos. Pero ahora encuentra nuevos y apremiantes motivos para reavivarse en personas sensibles y encausarse en acciones concretas. Los reclamos, las denuncias y las propuestas de un colectivo internacional conformado mayormente por intelectuales, científicos, activistas, dirigentes políticos

\footnotetext{
${ }^{1}$ Por razones de economía expresiva, con este término refiero a varias disciplinas que se interesan por la música y el sonido, tales como la etnomusicología, la musicología, la filosofía de la música, la sociología de la música, los estudios de música popular, la psicología de la música, entre otras.
} 
y artistas, bajo el nombre de Internacional Progresista, ${ }^{2}$ son ejemplos de acciones loables encaminadas a que esa utopía no se extinga dentro de los límites de la imaginación. Vivimos una coyuntura angustiante, incierta y tiznada por la tristeza de las pérdidas y el empobrecimiento de los sectores subalternizados. Quizás por todo eso, es a la vez una coyuntura particularmente propicia para comenzar a labrar, como promulga la Internacional, un mundo democrático, descolonizado, justo, igualitario, liberado, solidario, sostenible, ecológico, pacífico, poscapitalista, próspero y pluralista.

Ahora, ¿qué trastornos está causando la pandemia en el desarrollo de las investigaciones sobre música y en la difusión de sus logros? Desde el mes de marzo de 2020 en varios países se ha vedado el acceso a repositorios que son esenciales para el avance de las investigaciones y a zonas en las que se llevan a cabo trabajos de campo. Asimismo, se han reducido, cuando no suspendido, los contactos personales y la movilidad transfronteriza, lo cual tiene consecuencias significativas en la educación y en la realización de intercambios académicos, estancias de investigación, encuentros científicos y otras actividades. A pesar de todos estos escollos, gracias a la búsqueda de soluciones creativas y a un máximo aprovechamiento de las redes y los dispositivos digitales, en general las investigaciones y la divulgación de sus resultados no detuvieron su marcha. Aunque, sin lugar a dudas, hubo que resignar muchas áreas de confort y limitar o reformular objetivos.

Pero lo apremiante no es definir las estrategias más eficaces para continuar con la investigación en el escenario de las restricciones sanitarias ni hacer un balance de logros y pérdidas. La dramática situación mundial creada por el COVID-19 fija una agenda de responsabilidades para todas las disciplinas. Particularmente en el campo de la humanidades, la prioridad de esa agenda es un debate sobre el valor mismo del quehacer de las disciplinas que lo componen. En las áreas que nos reúnen, ese debate gravita entorno al rol que podrían cumplir las (etno)musicologías para paliar los efectos de la pandemia, para revertir las condiciones bajo la cuales ésta surgió y está siendo gestionada, y para evitar un escenario post-pandémico devastado, frágil y aun más desigual. Un sinceramiento radical, sin usuras, ajeno a las situaciones personales parece conducir a declarar la inutilidad coyuntural de las (etno)musicologías. Se trata de una inutilidad del aquí y ahora que reconoce que la experticia de estas disciplinas es inerme ante el virus y ante todos los estragos que éste ocasiona. No parece posible revertir este estado de cosas mediante el voluntarismo que proclama "ayudo con lo

${ }^{2}$ https://progressive.international/about/es 
que sé hacer", ni forzando las rutinas académicas hacia posiciones más decoloniales, colaborativas, deconstructivas o desjerarquizadas. Nada de esto evitará la propagación del virus y sus consecuencias. Si bien esas posiciones demostraron fehacientemente poseer un potencial crítico y transformador considerable, su eficacia debe ser repensada en esta coyuntura. En los últimos meses varios programas de investigación dirigidos a disminuir los efectos de la pandemia incluyeron financiación para las humanidades. Esa actitud parece originarse más en un esfuerzo de las instituciones por permanecer en la senda de lo políticamente correcto que en una confianza real en las soluciones o paliativos que esas disciplinas puedan ofrecer. Las investigaciones y cursos sobre el estado actual y post-pandémico de las actividades musicales y de los/as músicos/as que se están realizando o se prometen a futuro, saben más a oportunismo y a supervivencia individual que a la búsqueda de soluciones que afecten a los colectivos involucrados.

Si se acepta que las (etno)musicologías no poseen un repertorio específico de herramientas y postulados teóricos que sirvan para mitigar los efectos de la pandemia y/o para moldear un escenario post-pandémico más equitativo, ¿qué es lo que pueden aportar? Como otras disciplinas, las (etno)musicologías han tejido extensas redes y creado diferentes canales y órganos de difusión, por los cuales circulan los resultados de sus investigaciones, que podrían vehiculizar transitoriamente el tipo de discusiones que se están llevando a cabo en las ciencias sociales a nivel global. Para que eso ocurra es necesario vaciar parte de su contenido, es decir, deberíamos dejar provisoriamente de hacer análisis musical, de elucubrar sobre el carácter social de las músicas, de esforzarnos por catapultar nuestros nombres al primer plano de la escena mediante la generación de neologismos, de inventar constantemente subdisciplinas, de crear para todo "una perspectiva (etno)musicológica" y de muchas otras acciones meritorias y poco meritorias. El vacío que deje el abandono de esos temas y acciones podría ser llenado con cuestiones acuciantes que atañen a las condiciones de vida actuales y futuras y, por ende, a las condiciones de investigación y enseñanza. Es el momento de alejar a las (etno)musicologías de las humanidades y acercarlas más a las ciencias sociales, y dedicar parte de sus canales de diálogo a abordar los temas sobre los cuales estas ciencias hoy debaten: la cotización del agua en el mercado de futuros de Wall Street, la solvencia de los estados como cuestión política, ${ }^{3}$ la redistribución de la riqueza, el surgimiento y crecimiento de partidos políticos que cultivan el

${ }^{3}$ Ver https://www.project-syndicate.org/commentary/seven-secrets-revealed-by-2020-by-yanisvaroufakis-2020-12 
autoritarismo y el racismo, la intromisión de los laboratorios farmacéuticos y otras multinacionales en las decisiones de los estados soberanos, el acceso desigual a la salud y muchas otras cuestiones igualmente críticas y apremiantes. En síntesis, la propuesta consiste en dedicar temporalmente algunas páginas a demostrar nuestra responsabilidad hacia esa parte del mundo que siempre se lleva la peor parte. ¿Seremos capaces de hacerlo?, ¿seremos capaces de afrontar las consecuencias que esto genere? Este editorial pretende abrir el debate en esa dirección. 